\title{
Research Paper \\ A City Branding Framework in Regional Development Planning: The Case Study of Pringsewu Lampung
}

\author{
Citra Persada, Architectural Program, University of Lampung; Indonesia \\ Yunita Kesuma, Architectural Program, University of Lampung; Indonesia \\ Fadhilah Rusmiati, Architectural Program, University of Lampung; Indonesia
}

\begin{abstract}
The city branding shows the relation of the goals of managing the city's image that needs to be planned. The city branding is not about slogans, logos and promotional campaign, but it will be taken in practical program framework of the local development planning. The purpose of this paper is to identify an empirical city branding framework in Pringsewu, a historical area in Lampung Province. Then this paper will devise the strategies to increase a practical city branding. The research consist of three main phase: desk study, field research analysis and derived recommendation with practical city branding strategies framework. A qualitative approach is used by in-depth interviews with twelve respondent from local community figures, bureaucrats and academicians. Based on SWOT (Strength, Weakness, Opportunity and Threat) analysis of the qualitative data, the empirical programs of city branding in Pringsewu include logo and landmark. That is disengage in local development policy and regional planning, there is a weakness from practical city branding. As the result, we suggest that a bottom-up approach based on local community should be taken to developing a place brand strategies. The three elements in branding strategies accepted for Pringsewu: 1) involved and strengthen city branding in local development plan and strategies, 2) building revitalization of place branding infrastructure, 3) developing local community empowerment. A practical city branding could help a place to attract tourism, visitors, traders and investors then increase economic growth. The city branding can represent the community entity, geographical wideness, local development planning and potential local comodities. It provides a good starting point that would be the right strategies framework and practical approach for local development planning.
\end{abstract}

\section{Keywords}

City, Branding, Strategies, Pringsewu

\section{Introduction}

Nowadays, cities are forced to compete with each other to gain more tourist destination, workplace, cultural rich place and various forms and activity fields (Kotler, 2002). The competition among cities might be seen for fast changes in technology and the globalization (Kavaratzis, 2005). Cities are tried to search for new ways to promote themselves to be 
attractive to created the brand identity that would change the image of the city. City branding was found to be a backbone concept, while city marketing focuses on brand identity and brand image strategies includes construction, communication and management of the city's image to support the needs and expectations of customers (Krantz \& Schatzl, 1997 in Purwanto, 2017). For this case, cities develop strategies to support, to introduce and advertise them to "sell" their brand image in the global market. Most of the research study reveal that there are mainly three approaches for promoting cities: cultural events; restoration and promoting heritage; the construction of iconic buildings (Hankinson, 2006 ; Kavaratzis, 2005). In fact, many cities prefer to built construction of iconic buildings to get attention and attraction. The problems of this approaches for other cities are built it without considers branding concept, potential resources, policy and local development planning. The city branding shows the relation of the goals of managing the city's image that needs to be planned. The city branding is not about slogans, logos and promotional campaign, but it will be taken in practical program framework of the local development planning. This research aims to present city branding framework based on an empirical city branding phenomena, involving geographic, economic, social, cultural, and policy in Pringsewu REgency, a historical area in Lampung Province. Then this paper will devise the strategies to increase a practical city branding which involve potential effects on residents with combination of city branding measures and city marketing components. From a practical perspective, these findings could help stakeholder such as government, local tourism organizations and residents to create a sustainable strategy to develop their tourism destination. In this paper, there are three principal questions:

a. Have the city succeeded to forming "Bamboo City" as local branding and provides it within strategic developmental plans?

b. Why is it necessary to strengthen "Bamboo City" branding for Pringsewu Regency?

c. How can "Bamboo City" brand image be created in the social, economic and environmental strategies?

\section{Literature Review}

City branding is a methods to gain the attraction and establish city recognation (Rainisto, 2003). City branding is created to achieving competitive advantage, in order to increase investment income, tourism industry and community development. The city branding concept was reinforcing local identity and citizens identification with their city and activating all local resources (Kavaratzis, 2004). Nowadays, the branding of places and more specifically of cities, has gained an extraordinary momentum among city officials (Anholt, 2007). City as a brand have a purpose of promoting the existing and potential resources and trying assert their individualit to differentiate themselves from each other within various economic, political or socio-psychological objectives (Kavaratzis and Ashworth, 2005). Many cities and towns is living in a world where competition to start thinking about finding new ways to improve the image of the city with the purpose of attracting visitors. (Kotler et al.,2004).

City branding was a main concept to guide a city marketing strategies. City marketing focuses on brand identity and brand image strategies includes construction, communication and management of the city's image to support the needs and expectations of customers (Krantz \& Schatzl, 1997 in Purwanto, 2017). The most important success factor to created city 
marketing is the planning group, vision and strategic analysis, place identity and image, publicprivate partnerships and leadership (Rainisto, 2003).

In addition to the success factors above, to fullfil the challenges in an environment where the practice of city marketing is done, it is political public affairs, global market, regional development and process that coincidence of the marketing process. A framework for evaluating city branding, called the city brand Hexagon, is used to make the Anholt-GMI City Brands Index (Anholt, 2006 in Papp-Vary, 2011). Simon Anholt, a practitioner who is often credited in coining theterm 'nation branding',2 started the Nation Brands Index in 2005 and partnered up with GfK in 2008 (Anholt, 2011). Following the commercial success of Nation Brands Index, Anholt started the Anholt- Global Marketing Institute (GMI) City Brands Index. The current ACBI is surveyed by GfK Roper Public Affairs \& Corporate Communications (GfK America, 2013) The survey asks around 40 questions to 20,000 people from 20 countries about 50 cities, and is administered online (Anholt, 2006). ACBI has the six components of the hexagon for the characteristics of cities include the presence, place, potential, pulse, people and prerequisites.

"Presence [. . .] measures the city's global contribution in science, culture and governance. Place [explores] people's perceptions about the physical aspect of each city in terms of pleasantness of climate, cleanliness of environment and how attractive its buildings and parks are. Pre-requisites determines how people perceive the basic qualities of the city [.. . ] such as schools, hospitals, transportation and sports facilities. People [reveals] whether the inhabitants of the city are perceived as warm and welcoming, whether respondents think it would be easy for them to find and fit into a community that shares their language and culture and whether they would feel safe. Pulse [measures] the perception that there are interesting things to fill free time with and how exciting the city is perceived to be in regard to new things to discover. Potential [measures] the perception of economic and educational opportunities within the city [... " " GfK in 2008 in Anholt, 2011).

The six components of the characteristics of city's hexagon is possible to provide recommendations to decision makers to identify potential for intervention or to assess the effectiveness of branding projects. Kavaratzis (2004) showed the frame of a city brand communication through different variables, which have both functional and symbolic meanings. Primary Communication is related to city life or activity support are provided in four categories. There are landscape strategies, infrastructure projects, organisational and administrative structure dan the city's behavior. Secondary Communication for mediagenerate imagery branding and one of practical promoting programs like indoor and outdoor advertising, public relations, graphic design, logos, etc. Tertiary Communication created a "word of mouth" such a slogan,tagline and verbal branding for city to gain attention and attraction for strengthen city image.

This framework distinguishes between unintentional and intentional communication. Hankinson (2006) distinguishes four branding perspectives, namely; perception of the brand as an entity, brand as a brand communicator, Brand as a relationship, and brand as a major driver of value. Kavaratzis (2006) described the similarity of concepts covering the main lessons of corporate branding and marketing theories. The similarity of the frames are grouped into eight categories as a component of an integrated approach to managing city 
branding. These categories are: vision and strategy; internal culture; local communities; synergies; infrastructure; cityscape and gateways; opportunities; communications.

The concept of a sustainable city image is necessary to define visual image, city image and sustainability.The visual image is legible, real and tangible, contains many elements, defined as paths, edges, districts, nodes, and landmarks' (Lynch, 1960). The making of a good city image as planning strategies has become an essential need for cities in order to survive in the global market. Since successful city brand images give a unique brand image through certain strategies, which benefit beyond the physical aspects of city branding. There are different city branding strategies that could be developed based on diverse city development objectives and visions, such as monumental building construction projects, signed architecture, events, media, etc. The city branding strategies are not limited to the promotion of the city image, but it extends more, to change it for the interest of investors, politicians, real estate and construction projects, planners, architects, and other groups. That stand to profit from enhancing the role of their cities to support sustainable development strategies.

\section{Methods}

This paper explores the concept of city branding from theoretical and practical viewpoints based on "Bamboo City" Pringsewu Regency's branding case study. The research consist of three main phase: desk study, field research analysis and derived recommendation with practical city branding strategies framework. The first phase helped to identify and analyze the basic features of the government regulation, spatial development plans and city development strategies. Later the second phase, field research helped to analyze and collecting information based on existing experiences of Pringsewu branding strategies. It is undertaken by in-depth interviews with twelve respondents were selected for purposive sampling. Respondents including local community figures, bureaucrats and academicians. This research used a qualitative approach to determine branding tools information provided by SWOT (Strength, Weakness, Opportunity and Threat) analysis. This technique for evaluating and to develop a strategic planning based on a comparative analysis in different components of the social, economic and environmental indicators, as well as current and future potential. Then the last stage was concluding the framework of the important elements' in branding strategies.

\section{Discussions}

\subsection{Branding Strategies in Pringsewu}

Pringsewu is a regency of Lampung Province, Sumatera, Indonesia. It was spacial development from Tanggamus Regency under The Law of The Republic of Indonesia Number 48 of 2008 on The Regional Autonomy Legislation of Pringsewu Regency in Lampung Province. The regency name "Pringsewu" came from Javanese languange terms "sewu" (thousand) and "pring" (bamboo). From the histories, Pringsewu was a trasmigration development area in Sumatera under Dutch kolonial rule during the early 20th century. The people on Pringsewu are mostly coming from the transmigration program which is the descended migrants from Java, Madura and Bali. The goverment supported and allowed Javanese transmigrant to keep 
hold of their way of life including the language and social-cultural objects. It caused the unnamed land with bamboo forestry is called "pringsewu" then officially authorized on October 2008. Based on interview, "pringsewu" related to historical root of islamic development by K.H.Gholib in 18th centuries. He was islamic preacher who came from East Java into Sumatera and Johor, Malaysia. He well known as "kyai bambu seribu", a religious leader with respecting, tolerance and anti-discrimination in multiracial and multireligious society during Dutch kolonial. In 1927, he built Jami mosque and pesantrena (a place where students live and study Islamic knowledges) to develop islamic education in Pringsewu (Figure 1). It was a historical building in Pringsewu and K.H. Ghalid become street's name.

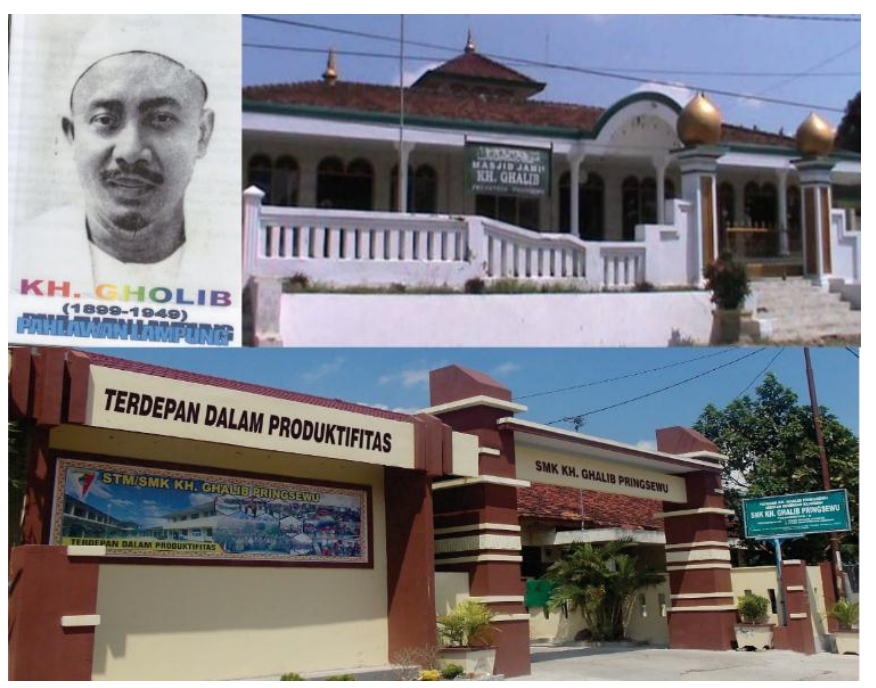

Figure 1 K.H Ghalib Jami Mosque and Pesantren in Pringsewu

(Source: http://perpusda.pringsewukab.go.id/)

"Bamboo City" branding was created by understanding and sosio-cultural histories from Pringsewu residents. The logo of Pringsewu which adopted bamboo philosophy and is listed in Regeant Rules and Regulation Number 11 of 2011. Due to the fact "Bamboo City" branding is not added in Spatial Regional Planning and Long Term Plan of Pringsewu Regency, it is biased toward city branding strategies. Based on reviewing and discussing with respondents, the branding is inconsiderate to the vision and strategic programs. City branding was a main concept to guide a city marketing strategies includes the construction building project, sociocultural development and economic strategies programs. Spatial plan and development strategies are one of the important success factor to created city marketing (Rainisto, 2003).

In fact, the city branding "bamboo city" was provide in visual media such in logo and landmarks but untoughtfully provides in slogan, tagline or public relation. The branding uncontinous to invest the effort to promoting "sell" Pringsewu with iconic identity in social, economic and environmental project. A city logo is a part of the core concepts that are visible to the consumer (Anholt, 2007). It was strengthening brand equity through increased awareness, recognition, and royalties ofcustomers (Wheeler, 2009). A city logo helps to steer public perception and effectively revives a positive image for the city. Besides, "bamboo city" was unmentioned in Pringsewu"s slogan. It was "Bumi Jejama Secancan" meaning of people holding hand to live a mutual life together (Figure 2). One of the important reasons is a unique 
brand identity in order to create a competitive advantage that will be recognized by global market, meaning of the city have a perception and basic knowledge of how the city.

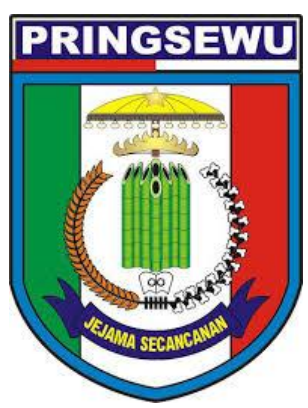

Figure 2 The Logo and Slogan of Pringsewu (Source: https://promgsewukab.com/)

Landmark was designed as statements of the city branding in architectural to generate enormous public interst. Such building have become brands in their own right and being a communication media to provides the city vision and development strategies. Landmark is used to reflect the consistency of the visual appearance for the goverment to strengthen the city branding. There are monument signs in Pringsewu describe a symbols of bamboo philosophy despite it wasnot made of the real bamboo material (Figure 3). Based on concepts and design, it was unfunctional building and lacking to being a succesfull attributes to provides "bamboo city" brand. Nothing building construction and designed provides bamboo as a building material. Bamboo as a building material has high compressive strength, low weight, renewable, extremely versatile and sustain in those locations where it is found in abudance. Bamboo material is used for the construction such scaffolding, structures, householding even high level buiding. It is one of the fastest growing plants than most other species of plants, which is conventionally suitable cultivated in Southeast Asia. Generally the landmark for "bamboo city" brand was lacking in innovative branding features.

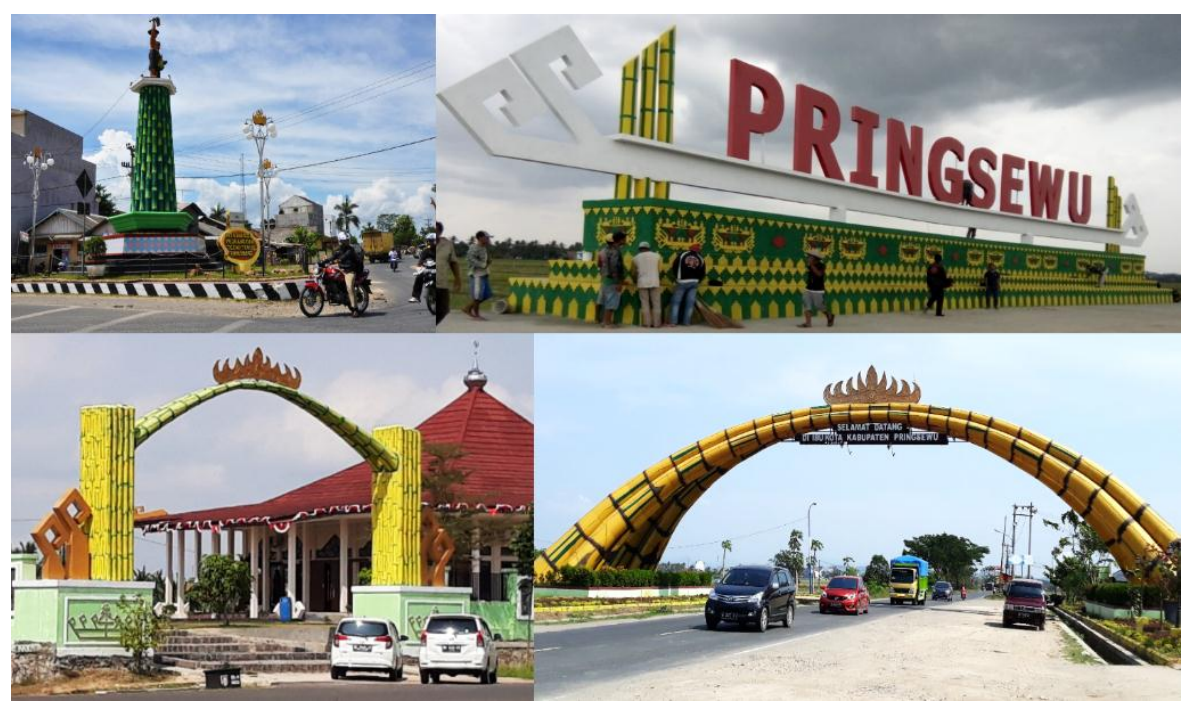

Figure 3 The Monument Signs in Pringsewu (Source: Researcher's documentation)

The Pringsewu's economic is dominated by agricultural such as farming, livestock comodities, trading and small scale manufacturing. most farming production initiatives such as grains, fruits and vegetables provide a source of food for people. The livestock comodities came from 
fishery, cattle industry and dairy product. There are modern grocery, wholesale market and traditional trading and home based small scale industry to offer as a economic contribution for Pringsewu's domestiic economic growth. A small scale manufacturing came from home based craft industries in Pagelaran District and Gadingrejo District. Unfortunatelly, most of this production has not been promoted largely and only offering for local trading markets.

Supporting cultural industries in Lampung Province, Pringsewu is chosen being host for the 8th and 9th Bambu Nusantara Festivals which is annual international events of Economic Creative and Tourism Ministry (Figure 4). It was held from May 15th to 16th 2014 and then in November 29th - 30 th 2015 at Pringsewu Government Field. Events is opened to all typo of performance including folk dance, folk music, traditional dance group,modern dance and traditional icon culinary. This festival features various product and attractions to develop and highlight bamboo as local potencials of Pringsewu identity. The cultural festivals attract culture tourist to local community events, it have contributed in the development of cultural tourism. Festivals have major impacts to promote the local potencials and the host communities. The local government as well private sectors and society in general have responsibility for tourism development and promotion to global market.

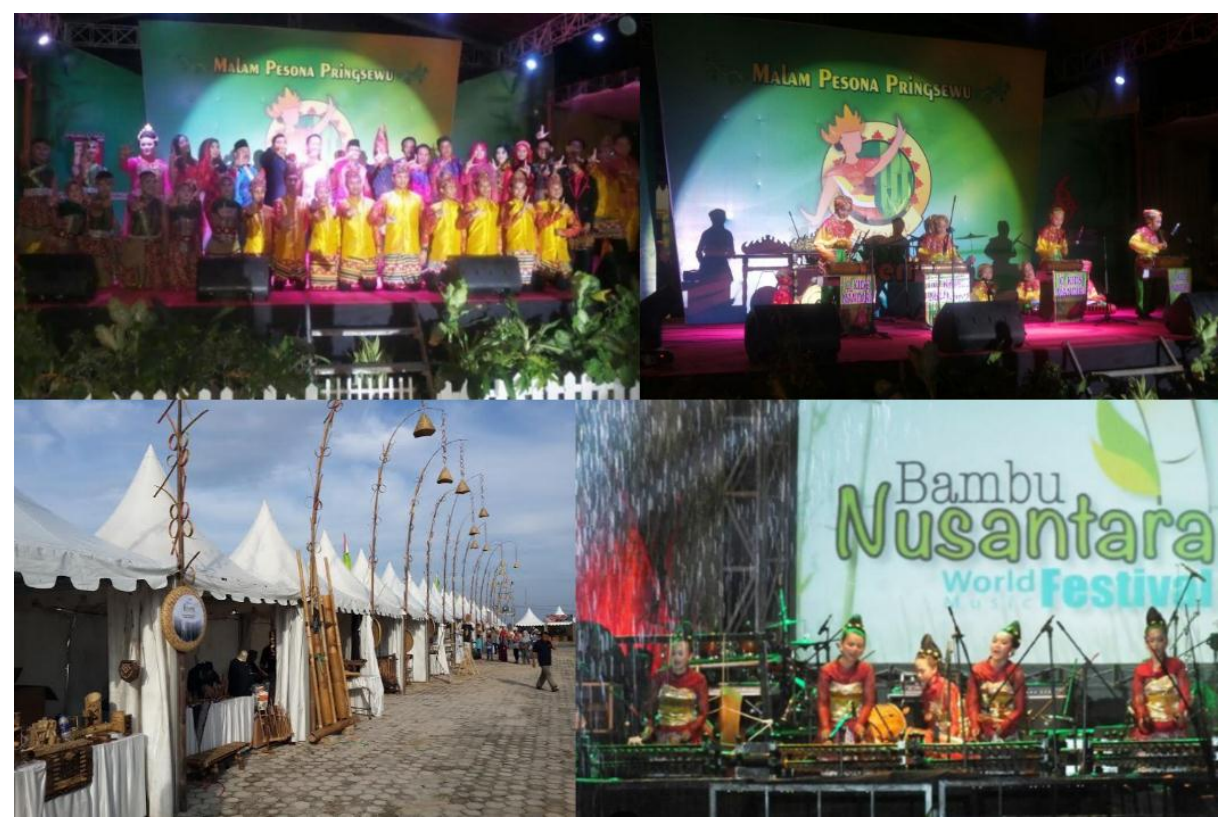

Figure 4 Cultural Events in Pringsewu (Source: Sumber: https://dutalampung.com/)

\subsection{City Branding Framework Based on Pringsewu case study}

Based on SWOT analysis provides potencials and weakness in "bamboo city" branding in economics, socio-cultural and envirinmental aspects. It can be the main boundary to establise integrated development strategies with preparing long term vision of Pringsewu's future focus on strengthening economic competitiveness. There are also covered and drawn a short term action plan. The process is participative and involving major stakeholders from all segments of society. There are involved place branding in local development policy and regional planning; building and revitalization of place branding infrastructure; developing local community empowerment (Figure 5). A practical city branding could help a place to attract tourism, visitors, traders and investors then increase economic growth. Place marketing 
enables a strategic approach to public planning in collaboration with the private sector. The city branding can represent the community entity, geographical wideness, local development planning and potential resources.

The city branding is stimulate a economic competitiveness which reveal advantages for the urban regeneration of the city. It is generally understood as a action plans to build the possitive image of the city and communicate it to global market within various features via visuals, narratives amd events. The objectives of city branding are: to attract tourism, to gain inward investment and to reinforce local identity of the citizens. Generally, city branding is a means to improve external and internal images of city. The city image should be reflected in the spatial structure of the city and being the potencial attractivenes for tourism. The city image marketing enables a strategic approach to public planning in collaboration with the private sector.

City branding consist of spatial and communication components. Primary communication is divided into spatial and non spatial aspecs. Spatial communication aimed to improve the physical quality of the city, such as built functional building which is made from bamboo as main material contruction, create a "bambu cultivation and creative production territory, and establish "bamboo city' eco-tourism development and infrastructure project. Non spatial communication deals with enhancement of socio-cultural development features, service provision, creating comprehensive community relations and event community organisation. The secondary communication is promotion of "bamboo city" image by interested parties, such as "bamboo city" eco-tourism project, bamboo cultivation activities and create cultural events or festivals to advertise the manufacturing of bamboo products globally. Furthermore, it is provides job opportunities and economic development strategies based on local community. Tertiary communication to create competitivenes, which reinforces "bamboo city" image and reflect it into city slogan, tagline, campaign and advertising to "sell" Pringsewu in the wide range of global market.

The main concept of practical city branding framework in pringsewu is investing in arts and culture being tourism and bussiness development features. Culture is a source of local economic growth, provides advantages as a source of employment and being value added in tourism and business. Culture helps and regenerates cities for creating integrated local economic strategies. The arts and culture features can actually contribute to increasing property values in these place by making neighbourhoods and creative industries more attractive to investors. As a histotical city, Pringsewu can be regarded as a cultural ecotourism destination to protects bamboo as local cultures and empowers the native community. Cultural eco-tourism is the subset of tourism that is concerned with the authenticity of city's lifestyle in certain environmental aspects, such as their entity, local comodities, arts, architecture, rituals, festivals and more values which help convey the culture of the city itself. Furthermore, the cultural eco-tourism conserves cultural traditions, promoting local comodities and improving local community welfare. 


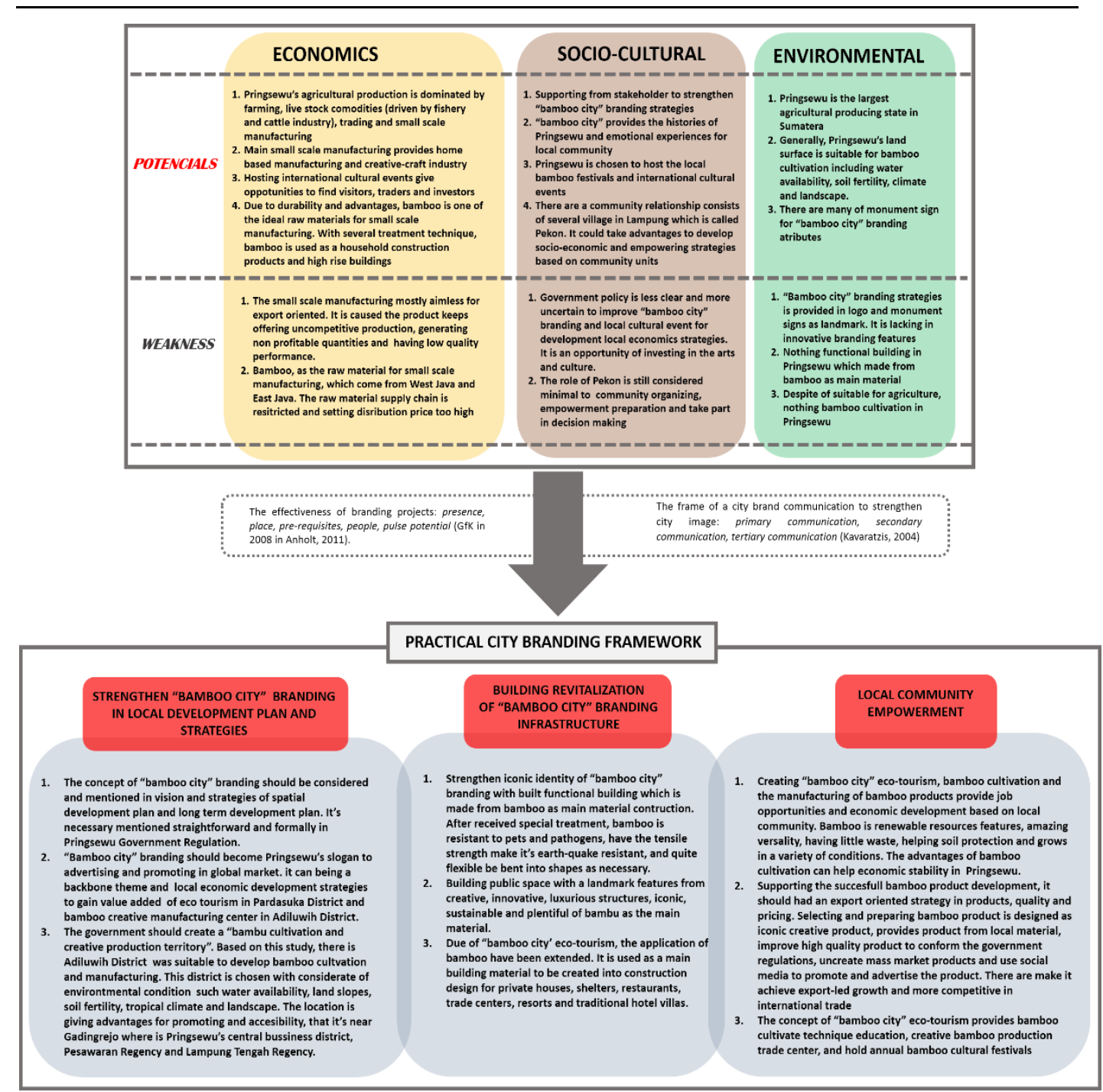

Figure 5 Practical City Branding Framework (Source: Researcher's analysis)

\section{Conclusion}

Based on Pringsewu case study, "bamboo city" branding strategies is provided in logo and monument signs as landmark. Nothing functional building in Pringsewu which made from bamboo material, that cause the image of "bamboo city" is uncertain and not giving emotion and experiences for visitors. The strategies of "bamboo city" branding is lacking in innovative branding features. The goverment and community supposed to create a new branding strategies for strengthen "bamboo city" in economy, socio-cultural and environmental aspect. The three elements in branding strategies accepted for Pringsewu: 1) involved and strengthen "bamboo city" branding in local development plan and strategies, 2) building revitalization of "bamboo city"branding infrastructure, 3) developing local community empowerment. A practical city branding framework helping a place to attract tourism, visitors, traders and investors then increase local economic growth. City branding was being a marketing strategies 
to represent the community entity, potential local comodities, and promoting the image of city in global market.

\section{Acknowledgements}

The authors gratefully acknowledge the generosity of the research participants in sharing their time, experiences and the support from community organisations, academicians and local governments. This study was funded by The Research Grant Programme from University of Lampung in 2018. This programme provides financially supports for academicians and scientific research to enhance their skills, knowledge, and experience through their own research work. Applications for The Research Grant Programme are reviewed by panels of academicians and scientific research experts in civil engeneering and environmental science fields of study.

\section{References}

Anholt, Simon (2007) Competitive Identity: The New Brand Management For Nations. London: Palgrave Macmillan.

Anholt, Simon (2006) "The Anholt - GMI City Brands Index. How the world sees the world's cities", Journal of Place Branding, Vol. 2 No. 1 ( January).

Anholt, Simon. (2011). Beyond the nation brand: The role of image and identity in international relations. In A. Pike (Ed.), Brands and branding geographies (pp. 289304). Northampton: Edward Elgar Publishing.

Chaerani, (2011). Pengaruh City Branding terhadap City Image (Studi Pencitraan Kota Solo: 'The Spirit of Java'). Solo, Indonesia: Universitas Sultan Ageng Tirtayasa Press.

Dril, Nataliya; Galkin, Andriy; Bibik Natalya (2016) "Applying city marketing as a tool to support sustainable development in small cities: case study in Ukraine" Transportation Research Procedia 16 ( 2016 ) 46-53 (March).

Hankinson, Graham (2006) "The management of destination brands: Five guiding principles based on recent developments in corporate branding theory", Journal of Brand Management, Vol. 14 No. 3 (March).

Indriani, Jesi; Kuswoyo, Chandra (2017) "Pengaruh City Branding Dan City Image Terhadap Keputusan Berkunjung Wisatawan Ke Kabupaten Purwakarta". Jurnal Manajemen Maranatha, Vol. 17 No. 1 (November).

Kasapi, Iris; Cela,Ariana (2017) "Destination Branding: A Review of the City Branding Literature", Mediterranean Journal of Social Sciences, Vol 8 No 4 (July).

Kavaratzis Michalis; Ashworth, G.J (2005) "City Branding: An Effective Assertion of Identity or A Transitory Marketing Trick". Journal of Place Branding, 2(3), 183-194 (February).

Kavaratzis, Michalis (2004) "From city marketing to city branding: Towards a theoretical framework for developing city brands. Journal of Place Branding", Vol. 1, No. 1(June). 
Kotler, P., G. Armstrong, (2004) Principles Of Marketing. Tenth Ed. New Jersey : Pearson Prentice Hall.

Krantz, M and Schatzl, L (1997). Marketing The City In: European Cities in Competition (eds), Jensen- Butler,C., Shachar, A., Weesep, J. (eds) 1997. Avebury: Ashgate Publishing Company.

Lynch, Kevin (1960) The Image of The City, London: The MIT Press.

Merrilees, Bill; Miller,Dale; Herington, Carmel (2008) “Antecedents of residents' city brand attitudes" Journal of Business Research, 362-367 (May).

Moilanen, Teemu \& Rainisto (2009) How to Brand Nations, Cities and Destinations, A Planning Book for Place Branding. USA: Palgrave Macmillan.

Moleong, Lexy (2007) MetOde Penelitian Kualitatif Edisi Revisi. Bandung; PT remaja Rosidakarya.

Papp-Vary, Árpád (2011)“The Anholt-Gmi City Brand Hexagon And The Saffron European City Brand Barometer: A Comparative Study". Regional and Business Studies, Vol 3 Suppl 1, 555-562.

Purwanto, Ujianto; Soliha, Euis (2017) "Influence of City Branding, Brand Identity, and Brand Image On Visiting Decision to Pekalongan City" Jurnal Bisnis \& Manajemen, Vol. XVIII, No. 1.

Prayogi, Pria Estu (2017) "Pemetaan Persepsi Masyarakat Pringsewu Tentang Branding Kabupaten Pringsewu sebagai Kota Bambu". Social and Political Departement, Universitas of Lampung.

Rainisto, Seppo.K.(2003) "Success Factors of Place marketing: A study of place marketing practices in Northern Europe and the United States". Doctoral Dissertation. Helsinki: University of Technology, Institute of Strategy and International Business.

Rehan, Mohammed Reeman (2013) "Urban branding as an effective sustainability tool in urban development" HBRC Journal (2014) 10, 222-230 (November).

Riyadi (2009) "Fenomena City Branding Pada Era Otonomi Daerah". Jurnal Bisnis dan Kewirausahaan, Vol. 5 No.1 (Maret).

Riza,Muge; Doratli,Naciye; Fasli, Mukaddes (2011) "City Branding and Identity" Procedia Social and Behavioral Sciences 35 ( 2012 ) 293 - 300 (Desember).

Sevin, H. Efe (2014) "Understanding cities through city brands: City branding as a social and semantic network" Cities 38 (2014) 47-56 (January).

Sugiarsono, Joko (2009). City branding Bukan Sekedar Membuat Logo dan Slogan. Jakarta: Salemba

Sugiyono (2006) Memahami Penelitian Kualitatif. Bandung:Alfabeta.

Wheeler, Alina (2009) Designing Brand Identity.New Jersey: John Wiley and Sons, Inc. 